This article was downloaded by: [Australian National University Library]

On: 9 April 2009

Access details: Access Details: [subscription number 907447645]

Publisher Routledge

Informa Ltd Registered in England and Wales Registered Number: 1072954 Registered office: Mortimer House, 37-41 Mortimer Street, London W1T 3JH, UK

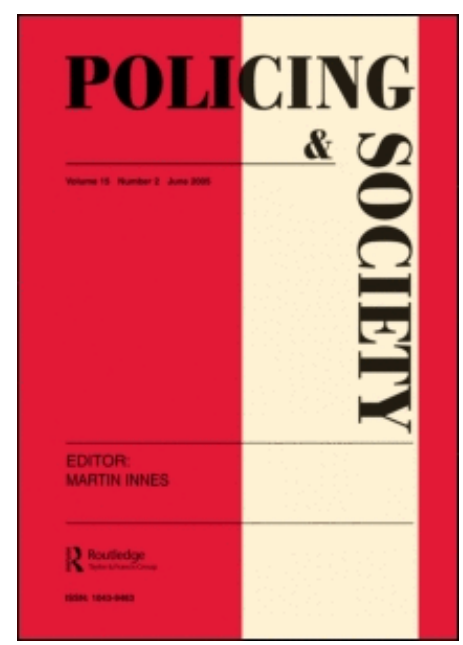

\title{
Policing and Society
}

Publication details, including instructions for authors and subscription information:

http://www.informaworld.com/smpp/title content=t713646669

\section{Policing in Cambodia: legitimacy in the making?}

Rod Broadhurst a; Thierry Bouhours ${ }^{b}$

${ }^{a}$ Key Centre for Ethics, Law, Justice and Governance, Griffith University, Queensland, Australia ${ }^{b}$ Faculty of Law, Queensland University of Technology, Queensland, Australia

First Published on: 03 December 2008

To cite this Article Broadhurst, Rod and Bouhours, Thierry(2008)'Policing in Cambodia: legitimacy in the making?',Policing and Society, To link to this Article: DOI: $10.1080 / 10439460802187589$

URL: http://dx.doi.org/10.1080/10439460802187589

\section{PLEASE SCROLL DOWN FOR ARTICLE}

\footnotetext{
Full terms and conditions of use: http://www.informaworld.com/terms-and-conditions-of-access.pdf

This article may be used for research, teaching and private study purposes. Any substantial or systematic reproduction, re-distribution, re-selling, loan or sub-licensing, systematic supply or distribution in any form to anyone is expressly forbidden.

The publisher does not give any warranty express or implied or make any representation that the contents will be complete or accurate or up to date. The accuracy of any instructions, formulae and drug doses should be independently verified with primary sources. The publisher shall not be liable for any loss, actions, claims, proceedings, demand or costs or damages whatsoever or howsoever caused arising directly or indirectly in connection with or arising out of the use of this material.
} 


\title{
Policing in Cambodia: legitimacy in the making?
}

\author{
Rod Broadhurst ${ }^{\mathrm{a} *}$ and Thierry Bouhours ${ }^{\mathrm{b}}$ \\ ${ }^{a}$ Key Centre for Ethics, Law, Justice and Governance, Griffith University, Queensland, Australia; \\ ${ }^{b}$ Faculty of Law, Queensland University of Technology, Queensland, Australia
}

(Received 4 January 2008; final version received 20 March 2008)

\begin{abstract}
Analyses of police statistics, newspaper reports, and United Nations International Crime Victim Surveys (UNICVS) are used to describe trends in crime and changes in perceptions of security, corruption and confidence in police in post-conflict Cambodia. These data show that both violent crimes (including homicides and police or vigilante killings) and property crimes have declined. Modest reductions in fear of crime are observed but confidence in police has not improved, although 'street-level' corruption is less frequent. Corruption, elite crime and consumer fraud remain serious problems consistent with Cambodia's 'fragile state' status. The emergence of juvenile and drug related crime reflects demographic changes and the impact of modernisation (and urbanisation) on cultural practices. The role of modernisation and democratic transition in shaping the form, response to and extent of crime is discussed, as well as the effect of international aid focussed on criminal justice assistance.
\end{abstract}

Keywords: Cambodia; corruption; crime; crime victim survey; modernisation; policing

\section{Introduction}

Long term Australian involvement in law enforcement capacity-building in post-conflict Cambodia provides an opportunity to assess the role of international aid in reforming policing practice. This article focuses on the community standing of police and the extent to which policing practices have achieved 'legitimacy' in Cambodia. We draw on the significant decline in the level of crime as measured by national police statistics, press reports and the United Nations International Crime Victim Surveys (UNICVS) conducted in 2001/2002 and repeated in 2006/2007. We suggest that the dramatic fall in the rates of 'street crime' is the result of a nexus of factors that include modernisation (i.e., marked socio-economic improvement supported by international aid), relative political stability and cultural resilience. However, regime capture, endemic corruption, especially in the criminal justice system and lower tolerance to these burdens has limited the positive effect that increased security may bring to state legitimacy.

As both violent and property crimes have declined (the latter dramatically in rural areas), functionalist perspectives have some explanatory purchase but do not account for the high levels of corruption, organised criminal activities (e.g., Global Witness 2007) and consumer fraud which are still evident. Indeed, predatory crime by elites remains a significant and unresolved legacy of the transition to an 'illiberal democracy' (Peou 2000, 2006) and regime continuities with the People's Republic of Kampuchea (PRK) and State of Cambodia (SOC). The potential emergence of a 'shadow' state and kleptocracy in the

*Corresponding author. Email: R.broadhurst@griffith.edu.au 
context of the rapid development of a market economy is also a significant constraint on the legitimacy of policing institutions. As the special representative of the UN Secretary General for Human Rights in Cambodia, Yash Ghai (2007) concluded in a recent report,

... [T] he absence of effective institutions of government, basic laws, and an impartial judiciary, accompanied by continuing impunity and threats against those who criticize the status quo, increasing landlessness, and growing numbers of displaced persons all leave Cambodia's citizens insecure, vulnerable to systemic denial and violations of their rights, and exposed to well-established methods for maintaining the existing economic and political order. (p. 1)

The concepts of 'police' and 'policing' are not indigenous to Khmer and 'the idea of the police' is relatively novel. Official rates of crime are remarkably low and are not simply the result of under-reporting and under-recording. Traditional concepts of order and authority are contextualised in patron-client relationships within a communitarian society governed by the ideals of Buddhist conduct. Peacekeeping and crime prevention are not usually externalised as activities of agencies such as the police, but remain, at least in rural areas, in the domain of village and commune chiefs. Social order and peacekeeping functions through social gossip, natural surveillance, reciprocal relations based on kin and village and long-standing practices of mediation and reparation. Only the most serious criminal matters gravitate to district and provincial centres and, therefore, to outside scrutiny.

The extreme case of Cambodia offers a unique window on how modernisation of both the state and economy modifies crime and violence (Arthur and Marenin 1995, Johnson and Monkkonen 1996). The Cambodian experience tests functionalist assumptions about how market development and state legitimacy suppress violence. Australia's 10-year plus engagement through the Cambodian Criminal Justice Assistance Project (CCJAP) to strengthen the rule of law also provides a rare opportunity to evaluate police reform in a transitional state. Crime victim surveys, the monitoring of reported violence and interviews with key players provide measures of change in the nature and prevalence of crime and lethal violence from which both the role of modernisation in a 'fragile state' (Anderson 2005) and the impact of the CCJAP can be assessed.

Assistance to police in developing states has evolved as a response to international and regional cooperation aimed at suppressing cross-border crime and terrorism. Cambodia, due to its history and socio-economic circumstances, poses such a risk, and Australia, with other countries has provided both financial and technical assistance to support crime prevention. It has also been assumed that developing police professionalism would support adherence to the rule of law and respect for human rights. A key motivation for assistance is national self-interest and the need to strengthen counter-measures via bilateral and regional policing assistance. Thus, assistance is designed to strengthen the capacity of developing countries to combat transnational criminal networks and to avoid the creation of criminal 'safe havens' (Broadhurst 2003).

In 2003, Australia provided AU\$39.6 million in aid to Cambodia (about 9\% of the total East Asia aid budget and one of the highest per capita) and about $15 \%$ of this figure was earmarked for better governance programmes. These funds also helped train and equip law enforcement for the challenges of local and global crime. Since 1997, the Australian government has provided CCJAP with AU\$30.6 million ${ }^{1}$ to strengthen the rule of law via police reform processes. A further AU\$30 million is now being provided in Phase III (2007-2012) to support selected legal and judicial reforms consistent with priorities set by the Council of Legal and Judicial Reform in the light of the Royal Government of Cambodia's (RGC) National Strategic Development Plan (2006-2011). Priorities for aid are likely to be focused on juvenile crime, sustainable management of prisons and 
corruption (AusAID 2007a,b). Reviews of earlier phases were critical of the effectiveness of the police-training component and have not endorsed significant further effort in Phase III (AusAID 2007b).

Overcoming problems in establishing effective policing in fragile states is a crucial factor in developing stable democratic governance (e.g., Donias 2005, with respect to Haiti; Bertrand 2004, for Indonesia). Measures of police performance and crime reduction (e.g., violence, fear of crime and confidence in police) are used to assess the level of security and the legitimacy of RGC law enforcement. Evidence from the UNICVS, attitudes to corruption, official crime statistics, extra-judicial homicides, election violence and interviews with Australian and Khmer participants are combined to assess the RGC's standing as a 'state of concern'. This article therefore adds to the literature about the effectiveness of international policing assistance to post-conflict states and the nature of violent crime during state formation.

We track key indicators of crime and security in Cambodia over 15 years (1992-2007). Data from several sources are used to estimate changes in violence as measured by homicide incidents, other violent and property crime victimisation, election violence and vigilantism, as well as attitudes towards crime and corruption. The prevalence of homicide and the severity of violence in Cambodia have been detailed and a decline in homicide has been observed (Broadhurst 2006). More recent data (as presented below) confirm this trend, which extends to crime in general. Why this has happened and what role the police have played in reducing crime is unclear. However, improvements in socio-economic standing, reductions in the availability of small arms and political stability are significant factors.

Both concepts of wealth and political stability are used here in a relative sense. In relation to socio-economic improvements, GDP per capita has increased from approximately US\$160 in 1992 to US\$384 in 2006. General improvements in living standards have been observed. Infant and child mortality, illiteracy and TB have declined. The education level of girls has improved, although universal primary education has not yet been achieved and one-third of the population remains illiterate. Life expectancy is only 56.4 years; however, this is already an improvement on conditions in 1992 when life expectancy was estimated to be about 53 years. Some $35 \%$ of Cambodians were still under the national poverty line in 2004, but this was better than the estimated 47\% in 1994 (Murshid 1998, Men et al. 2005). Recent socio-economic data show further improvements and significant uptake of modern media and communication. UNICVS data suggests that most respondents also note improvements in economic standing. Since 2000, economic growth has averaged over 7\% per annum and foreign direct investment has increased from US\$129 million in 2000 to US\$358 million in 2005. Recent economic indicators show a rapidly expanding economy that is forecast to grow at around 9\% per annum (ADB 2007). However, the government is still aid-dependent, relying on donor countries for approximately $50 \%$ of its revenue.

With the slow but final demise of organised armed struggle between 1993 and 1998 , political stability and the reduction of electoral violence have also occurred. Forty years of conflict, including revolutionary genocide, Vietnamese occupation and civil war theoretically ended with the UN interventions of 1991-1993 and the first national elections. The subsequent forced alliance of Royalist democrats (Funcinpec) and the former SOC Vietnamese-supported Cambodian People's Party (CPP) was inherently unstable and led to the 1997 coup d' état and political violence during the second national elections of 1998. However, the 1998 elections completed the demise of the Khmer Rouge already seriously weakened by defections to either the Royalists or CPP. 
Regime stability was firmly established after the 2003 third national elections with the political alliance that arose in 2004 between the CPP and a greatly weakened Funcinpec. In effect, this was the eclipse of the discredited Royalist alliance and heralded the complete political domination of the CPP. In turn, the CPP had itself become dominated by Prime Minister Hun Sen supported by a formidable praetorian guard and ' . . power rather than the rule of law remain[ed] a reality' (Peou 2006, p. 57). The dominance of the CPP was clear with the overwhelming support it won in the first commune elections of 2002, especially in the rural areas where CPP activities had traditionally focused. The second commune elections in 2007 consolidated the position of the CPP even further and suggested that the 2008 national elections will continue to strengthen its political dominance. Once composed of former communists who are now unabashed modernists and capitalists, the CPP is set to remain the dominant power bloc for the foreseeable future.

\section{Theories of crime, modernisation and development}

Functionalist theories of modernisation suggests that, development will reduce violent crime, while at the same time increasing property and other crimes (notably those against the state, e.g., regulatory offences and corruption) as the rationalisation of modern governance is achieved (Durkheim 1950). Modernisation requires a shift in economic modes of production from feudal/mercantilist to industrial forms or from 'Asiatic' command to market economies. This shift in productive forces produces greater individualism and a significant middle class, weakens communal regulation, changes the nature of relationships from hierarchical to exchange and moves social control from informal to formal modes. Shifts from state command economies to 'free' markets are also accompanied by higher risks of corruption and plunder.

In functionalist versions, modernisation in its early phases increases differences between rural and urban life and generates acquisitive crime by weakening social control and unleashing expectations, but reduces violent crime. In late modernisation, the gap between rural and urban life diminishes, but violence may increase as conflict re-emerges due to rapidly changing modes of production and the fragmentation of post-modern identities. Modernisation is usually measured by economic development and, following the European experience, the degree of urbanisation. Research so far has not found a clear association between economic development and homicide, but has found a significant relationship between the latter and urbanisation (Alvazzi del Frate 1998, LaFree 1999, Newman 1999). As noted, Cambodia is one of the least economically developed and urbanised countries in the region. Thus, if functionalist theories about modernisation in Cambodia apply, then in an early phase, violent crime should decline while property crime increases and differences between the countryside and town are accentuated.

Cultural integration or homogeneity, often associated with Durkheim's (1950) idea of 'organic solidarity' and measured by fidelity to religious, linguistic and customary beliefs, has also been hypothesised as a factor in societies enjoying low rates of violent crimes. However, studies of the relationship between culture and homicide, using measures of religious and ethnic homogeneity, have not found a consistent pattern (see, for instance, Neopolitan 1997). Although significant numbers of Mhong, Cham and ethnic Vietnamese reside in some locations, overall, with more than 94\% Buddhists, Cambodia has a high degree of religious homogeneity, which could play a positive role in the changes to its rate of violent crime. Moreover, according to Elias (1994), the civilising (or socialising) effects of modernisation render violence more problematic so that the latter is subjected to an 
intensified criminalisation process when combined with an increasing reliance on bureaucratic surveillance and special policing institutions.

The role of the 'rational' state through its security management (i.e., monopolisation of violence) and welfare functions is crucial in this civilising process. By improving health services, livelihood security, literacy and suppressing crime, the state legitimates its governance. As a 're-organisation episode', Cambodia offers an opportunity to observe the nature of crime following a state-induced 'collective disaster' (Evans et al. 1985) and how, in the process of state formation, the establishment of a criminal justice system impacts on the prevalence of crime (notably homicide) and perceptions of security. For example, according to Archer and Gartner (1976), one of the effects of war is increased peacetime homicide arising from officially sanctioned wartime violence. Cambodia has been exposed to this 'legitimation of violence' mechanism and had a high peacetime homicide rate which, despite the absence of reliable data on pre-war crime to confirm this hypothesis, might arguably have been the result of state-legitimated wartime violence carrying through into a higher homicide rate in peacetime.

Following decades of war, genocide and civil dislocation, Cambodia has since undergone state formation and democratisation, and experiences crime differently to that of established states. The political settlement that led to the re-creation of a constitutional monarchy in 1993 required the formation of a new state. However, the law and order institutions of this new state did not enjoy public support and legitimacy (Peou 2000, 2006, Broadhurst 2002). The absence of an established legal culture restricted the RGC's ability to assert a credible threat to crime and disorder.

Following other explanatory theories of cross-national differences in violence (such as opportunity/stress theories) crime and disorder in the new and fragile SOC might be the result of changes in the pool of potential offenders and opportunities for violence that vary according to economic and social hardships. Thus the relative size of high risk groups (young unemployed males), population density, household size, income inequality, unemployment and infant mortality have all been employed with varying degrees of success as determinants of violence. Cambodia, with its exceptionally young population, acute levels of income inequality and relatively high under-employment (reliable data on unemployment rates are unavailable) could also be vulnerable to higher risks of violence. Competition over scarce resources may be reflected in the high levels of robbery - murder (i.e., lethal robberies) that have been observed in Cambodia (Daly Wilson 1999).

\section{Methodology and results}

Three main sources of crime data supplemented by in-depth interviews with CCJAP staff and key Khmer stakeholders, as well as socio-economic trend data have been used in this research. A major component of the study was a repeat of the UNICVS first conducted in 2001 in order to measure changes in the crime victimisation experience, reasons for reporting or not reporting crime to police, fear of crime, attitudes to punishment and trust of police and other government officials. The UNICVS does not include homicide events; therefore, additional sources (e.g., newspaper crime reports) as well as official statistics were used. The objective was to acquire multiple measures of the level of crime and insecurity in Cambodia for 1992-2007 with the emphasis on the periods 1997-2001 and 2002-2007 that coincide with the two distinct funding phases of the CCJAP (AusAID 2001). The latter period represents a concerted effort at developing district and provincial crime prevention programmes while the earlier period was an 'indirect' phase focused on training, police reform and infrastructure development. With such data, theory testing and 
an evaluation of the impact of criminal justice reforms and crime reduction programmes in the context of economic and political development can be attempted.

\section{Official crime reports}

Crime recorded by the police from 1992 onwards is reported in Table 1. The overall rates of recorded crime through 1992-2005 have varied between a low 30.3 (in 1994) and a high 58.5 (in 1998) per 100,000 population, and are low by comparison with developed states (see Broadhurst 2002). Since 1998, crime rates have steadily decreased to only 32.4 per 100,000 in 2005. Estimates of homicide victims including suspect death, grenade events and common murder/manslaughter drawn from RGC judicial police and other sources from 1992-2005 (not reported in Table 1) show that suspect death and grenade events have become less frequent while overall rates of homicide victims have fluctuated between a high 12.9 per 100,000 in 1993 and a low 3.8 per 100,000 in 2005. However, police statistics under-report crime (they measure police activity rather than criminal activity) and are often inaccurate and therefore supplemented by crime victim surveys and newspaper data.

\section{Newspaper crime reports}

From 1998 onwards, crimes reported by Cambodian newspapers were also monitored with special attention to vigilante and extra judicial homicides. Changes in the type of crime reported by the press as well as a decline in vigilante and police killings were indicated. In $1998,32 \%$ of homicides reported by the press involved police, military/militia or vigilante action, but this had fallen to $8.8 \%$ in 2006 . Such data measure police probity and decreases in extra-judicial homicides may indicate a strengthening of the rule of law; however, newspaper reports of homicides and other fatalities may not be a reliable index of these events. Nevertheless, the proportion of homicides among crime stories had also reduced from that reported in 1998.

Estimates of political and election related violence compiled by the UN and other human rights groups also show reductions. National elections in 1993 and 1998 were among the most violent, although this was not repeated in the 2003 elections. Hughes (2006) notes that the frequency of politically motivated killings has declined, but they remain potent symbols of the continued role of political violence. Data compiled from secondary sources (i.e., UN Office of Human Rights in Cambodia and local civil society NGOs), police and newspaper sources do suggest that some political violence occurred in 2004 and was associated with the post-2003 election stalemate that remained unresolved until mid-2004 (newspapers reports showed a peak in vigilante actions in 2004 compared to 1999-2003 and 2005-2006). National elections in 2008 will offer a further opportunity to observe shifts in presumed associations between violence and politics.

\section{Crime victim surveys}

The first Cambodian UNICVS was conducted in 2001 in Phnom Penh and five geographically representative provinces (i.e., Kampot, Kampong Cham, Kampong Spueu, Kandal, and Kampong Chhnang). The second survey was completed in two stages: first in Phnom Penh and Kandal in October 2006 and, using the same procedure, in Kampong Cham in October-November 2007. It was administered as a face-to-face household survey 
Table 1. Crime trends recorded by judicial police 1992-2005.

\begin{tabular}{|c|c|c|c|c|c|c|c|c|c|c|c|c|c|c|}
\hline & 1992 & 1993 & 1994 & 1995 & 1996 & 1997 & 1998 & 1999 & 2000 & 2001 & 2002 & 2003 & 2004 & 2005 \\
\hline & \multicolumn{14}{|c|}{ Number of recorded crime events } \\
\hline Murder & 429 & 599 & 303 & 397 & 542 & 317 & 793 & 581 & 571 & 407 & 425 & 509 & 511 & 448 \\
\hline Armed robbery & 1414 & 1613 & 905 & 832 & 1345 & 887 & 1822 & 1396 & 1252 & $1296^{\mathrm{a}}$ & $1419^{\mathrm{a}}$ & 1175 & 1320 & 868 \\
\hline Grenade attack & 40 & 157 & 79 & 27 & 54 & 46 & 68 & 42 & 39 & 21 & 10 & 23 & 33 & 20 \\
\hline Rape & 106 & 43 & 39 & 84 & 122 & 46 & 130 & 165 & 209 & $218^{\mathrm{a}}$ & $279^{\mathrm{a}}$ & 331 & 281 & 254 \\
\hline Kidnap $^{\text {b }}$ & 9 & 93 & 133 & 24 & 44 & 23 & 130 & 91 & 63 & 51 & 38 & 25 & 7 & 10 \\
\hline Poisons ${ }^{\mathrm{b}}$ & 14 & 47 & 42 & 23 & 24 & 21 & 0 & 20 & 31 & $\mathrm{n} / \mathrm{a}$ & $\mathrm{n} / \mathrm{a}$ & 6 & $\mathrm{n} / \mathrm{a}$ & $\mathrm{n} / \mathrm{a}$ \\
\hline Patrimony $^{\mathrm{c}}$ & 8 & 6 & 20 & 12 & 6 & $\mathrm{n} / \mathrm{a}$ & $\mathrm{n} / \mathrm{a}$ & 2 & 4 & $\mathrm{n} / \mathrm{a}$ & $\mathrm{n} / \mathrm{a}$ & $\mathrm{n} / \mathrm{a}$ & $\mathrm{n} / \mathrm{a}$ & 3 \\
\hline Theft & 1420 & 792 & 835 & 896 & 1471 & 868 & 1871 & 1789 & 1827 & 1854 & 1846 & 1741 & 1503 & 1458 \\
\hline Assault/disputes ${ }^{\mathrm{d}}$ & 515 & 267 & 353 & 423 & 1050 & 445 & 1114 & 1058 & 1130 & 1131 & 1141 & 1301 & 1024 & 1010 \\
\hline Fraud/pick-pocket ${ }^{\mathrm{e}}$ & 23 & 117 & 163 & 214 & 233 & 97 & 244 & 246 & 218 & $116^{\mathrm{f}}$ & $202^{\mathrm{f}}$ & $160^{\mathrm{f}}$ & $113^{\mathrm{f}}$ & $104^{\mathrm{f}}$ \\
\hline Illegal weapon & 136 & 514 & 235 & 310 & 79 & $\mathrm{n} / \mathrm{a}$ & $\mathrm{n} / \mathrm{a}$ & $\mathrm{n} / \mathrm{a}$ & 96 & 67 & 76 & 64 & 43 & 43 \\
\hline Other offences & $\mathrm{n} / \mathrm{a}$ & $\mathrm{n} / \mathrm{a}$ & 20 & $\mathrm{n} / \mathrm{a}$ & 668 & 208 & 905 & 639 & $387^{\mathrm{g}}$ & $381^{\mathrm{g}}$ & $309^{\mathrm{g}}$ & $358^{\mathrm{g}}$ & 161 & $256^{\mathrm{g}}$ \\
\hline All crime & 4114 & 4248 & 3031 & 3260 & $5638^{\mathrm{h}}$ & 2958 & 7077 & 6029 & 5827 & 5542 & 5745 & 5693 & 4996 & 4474 \\
\hline Rate per 100,000 & 45.7 & 44.7 & 30.3 & 31.5 & 51.2 & 25.5 & 58.5 & 48.6 & 46.2 & 43.3 & 44.2 & 42.8 & 37.0 & 32.4 \\
\hline Population (mil.) & 9.0 & 9.5 & 10.0 & 10.5 & 11.0 & 11.6 & 12.1 & 12.4 & 12.6 & 12.8 & 13.0 & 13.3 & 13.5 & 13.8 \\
\hline
\end{tabular}

Sources: 1998, 1999-2003, 2005 annual returns MOI Judicial Police Centre; 1997 data incomplete.

Notes: $\mathrm{n} / \mathrm{a}=$ not available; ${ }^{\mathrm{a}}$ also counts robbery and rape murder; ${ }^{\mathrm{b}}$ poisoning and kidnapping are presumed non-fatal; ${ }^{\mathrm{c}}$ theft of cultural heritage; ${ }^{\mathrm{d}}$ records only injurious assaults; ${ }^{e}$ offences combined in original source; ${ }^{f}$ pick-pocketing counted in theft from 2001 ; ${ }^{g}$ attempt killing is included: $2000=51,2001=153,2002=102,2003=87,2005=$

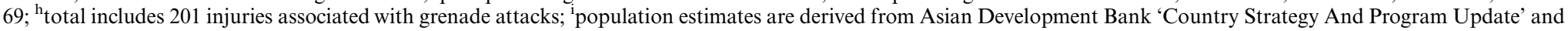
are approximate; all data revised December 2007. 
( $N=2300$ in the first sweep ${ }^{2}$ and $N=2517$ in the second). The crimes covered included: car theft, theft from cars, car vandalism, bicycle and motorcycle theft, livestock theft, attempted and successful burglary, personal theft, consumer fraud, assault (including sexual assault), robbery and corruption. A survey of mortality including suicide and homicide incidents in every participating household (a total of 790 households and 4683 individuals in 2007) was incorporated in the revised UNICVS protocol for the 2007 sweep of Kampong Cham. No suicide and two homicides were reported over the past five years. UNICVS also asked general questions about the reporting behaviour of victims, fear of crime, satisfaction with police and attitudes to crime and punishment.

The annual prevalence of crime estimated from the first and second surveys showed significant declines in crime victimisation across all offence categories with declines in Kampong Cham the most dramatic. Small increases in robbery and bicycle theft were observed in Kandal but these were the only exceptions (see Table 2). For example, motorcycle theft, burglary and livestock theft all showed dramatic declines. The observed reductions in crime, while substantial, still revealed large gaps between the experience of victims and the records of police. Willingness to report crime to police showed some increase in motorcycle theft and rape, but in general, victims remained reluctant to call on police.

However, field interviews with key commune officials (i.e., Village Heads, Post Police, Commune Chiefs and Clerks) revealed that citizens frequently report crime, especially in rural areas, to the Village or Commune Chiefs in the first instance, but these are often not recorded by police at the district, provincial or national level. Thus, like official police data, the UNICVS underestimate the 'reporting' level of crime victims. Respondents often referred to the problems of reporting crime to the police in terms of the costs: police often demanded 'petrol money' or other fees (i.e., bribes) before taking action. Questions about reporting behaviour are especially useful in measuring confidence in the police and other criminal justice agencies, while questions about fear of crime gauge citizen's assessments of security (see below and Skogan 2007).

The decline in violent victimisation can be partly explained by the civilising effect of modernisation. For instance, the general improvement in the socio-economic circumstances of many citizens (observed during the Kampong Cham UNICVS) has lessened the incidence of violent predatory crimes such as robbery motivated by extreme deprivation. However, the simultaneous decline in non-violent property crime does not support the traditional functionalist hypothesis that with greater materialism and insatiable desire for possessions, modernisation also brings a sharp rise in property crime. Here a cultural interpretation, which can also account for the low levels of reporting crime to the police and a general mistrust of state institutions, seems more appropriate. Strong Buddhist values and traditional forms of social control also help to inhibit criminal victimisation. While regime capture and corruption are likely to generate distrust in state institutions, manifested for instance in the unwillingness to report crimes to the police, there is also an enduring culture of self-help that has seldom relied on the central state to manage conflicts.

\section{Fear of crime}

Over two-fifths of Phnom Penh respondents in our first and second sweeps felt unsafe or very unsafe 'walking alone in (their) area after dark' (46.5\% in 2001 and $41 \%$ in 2006). In Kandal, fewer respondents felt unsafe (39.5\% in 2001 and $33 \% 2006)$, as did those in Kampong Cham (33.6\%-30.4\%). Respondents also felt much safer 'at home after dark' 
Table 2. One-year victimisation estimates and \% report to police in Phnom Penh, Kandal, and Kampong Cham 2000 and $2005-2006$.

\begin{tabular}{|c|c|c|c|c|c|c|c|c|c|c|c|c|}
\hline \multirow[b]{3}{*}{ Crimes } & \multicolumn{4}{|c|}{ Phnom Penh } & \multicolumn{4}{|c|}{ Kandal } & \multicolumn{4}{|c|}{ Kampong Cham } \\
\hline & \multicolumn{2}{|c|}{2000} & \multicolumn{2}{|c|}{2005} & \multicolumn{2}{|c|}{2000} & \multicolumn{2}{|c|}{2005} & \multicolumn{2}{|c|}{2000} & \multicolumn{2}{|c|}{2006} \\
\hline & $\%$ vic & $\%$ rep & $\%$ vic & $\%$ rep & $\%$ vic & $\%$ rep & $\%$ vic & $\%$ rep & $\%$ vic & $\%$ rep & $\%$ vic & $\%$ rep \\
\hline Car theft $\mathrm{t}^{\mathrm{a}}$ & 1.3 & 100.0 & 0.0 & 0.0 & 1.5 & 100.0 & 0.0 & 0.0 & 0.0 & 0.0 & 0.0 & 0.0 \\
\hline From car ${ }^{\mathrm{a}}$ & 20.5 & 4.3 & 4.3 & 10.0 & 15.2 & 0.0 & 3.6 & 0.0 & 8.3 & 0.0 & 5.7 & 0.0 \\
\hline Car vandal $^{\mathrm{a}}$ & 2.6 & 0.0 & 1.7 & 0.0 & 1.5 & 0.0 & 3.6 & 33.3 & 0.0 & 0.0 & 0.0 & 0.0 \\
\hline Moto theft ${ }^{\mathrm{a}}$ & 7.7 & 61.5 & 2.4 & 69.6 & 4.5 & 46.7 & 4.2 & 66.7 & 5.4 & 46.7 & 1.0 & 50.0 \\
\hline Bicycle theft ${ }^{\mathrm{a}}$ & 9.9 & 10.9 & 5.8 & 2.4 & 6.7 & 8.7 & 7.6 & 5.3 & 14.7 & 13.8 & 3.1 & 0.0 \\
\hline Livestock $^{\mathrm{a}}$ & 20.0 & 5.3 & 8.2 & 0.0 & 19.1 & 1.8 & 13.6 & 0.0 & 24.8 & 8.9 & 11.1 & 1.3 \\
\hline Burglary & 16.2 & 16.2 & 7.5 & 18.3 & 10.5 & 10.0 & 6.1 & 15.4 & 12.7 & 11.4 & 2.2 & 0.0 \\
\hline A/burglary & 7.8 & 31.5 & 2.7 & 6.9 & 5.2 & 20.0 & 3.5 & 18.2 & 7.6 & 45.2 & 1.6 & 15.4 \\
\hline Fraud & 39.6 & 5.7 & 25.4 & 6.5 & 31.8 & 5.5 & 18.7 & 1.7 & 29.8 & 2.4 & 22.0 & 4.6 \\
\hline Corruption & 27.8 & 1.2 & 18.2 & 1.0 & 18.5 & 1.9 & 18.3 & 3.4 & 15.6 & 1.2 & 12.9 & 5.9 \\
\hline Person theft & 13.8 & 8.6 & 6.5 & 9.9 & 5.2 & 3.3 & 3.1 & 0.0 & 7.3 & 10.0 & 2.3 & 5.6 \\
\hline Robbery & 1.9 & 45.5 & 1.5 & 62.5 & 0.3 & 100.0 & 0.6 & 50.0 & 0.9 & 100.0 & 0.1 & 0.0 \\
\hline Assault/threat & 7.8 & 27.2 & 2.0 & 27.3 & 4.4 & 28.0 & 2.8 & 27.8 & 6.2 & 29.4 & 2.3 & 44.4 \\
\hline Sexual assault ${ }^{\mathrm{b}}$ & 1.8 & 8.3 & 0.2 & 50.0 & 0.3 & 0.0 & 0.0 & 0.0 & 0.3 & 0.0 & 0.0 & 0.0 \\
\hline
\end{tabular}

Notes: ${ }^{\mathrm{a}} \%$ victimised calculated on number of owners; ${ }^{\mathrm{b}} \%$ victimised calculated on number of females; $\%$ vic (percent victimised) based on one-year prevalence; $\%$ rep (percent reported) calculated on number of victims; for Phnom Penh and Kandal UNICVS 2001 and 2006, one-year estimates, respectively, correspond to 2000 and 2005; for

Kampong Cham UNICVS 2001 and 2007, one-year estimates, respectively, correspond to 2000 and 2006. 
with $29.5 \%$ feeling unsafe or very unsafe in Phnom Penh in 2006 compared with $39.5 \%$ in 2001 while in Kandal, the proportion fell from $34 \%$ to $25.5 \%$ and in Kampong Cham from $27 \%$ to $22 \%$. Overall, more respondents felt safe in 2006 when compared to 2001 . The decline in fear as well as in the perception of the risk of burglary may be associated with the decline in the risk of crime noted by the UNICVS. By controlling political violence, regime stability has played a role in lessening feelings of insecurity, but again, cultural factors also play a significant role. Communitarian attitudes generally prevail in Cambodia and individualism is not privileged as in the West. For example, more than $95 \%$ of the UNICVS respondents declared that in their area 'most people helped each other'. Such perceptions are likely to help build confidence, self-help and feeling of safety.

\section{Public perceptions of police}

In general, Cambodians are less satisfied with their police services than they were in 2001/ 2002. Police enjoy some degree of legitimacy - a legitimacy that is conditional on a modicum of service and an absence of rent-seeking. Differences between the policing services are not measured, but in the case of rural villages, 'post police' or local police are the usual focus of respondents. In our interviews with local Village Heads and commune officials, problems of under-policing, poor equipment and inadequate numbers were noted (e.g., one commune had a police establishment of nine officers but only three were posted to the commune). Often, reinforcements were slow to arrive and offenders had eluded arrest. A key factor in the legitimacy of police is the very notion that, if the police are called, they will come and order and justice can be restored. If the citizen believes this to be the case, then the mere threat of 'calling the police' amplifies the efficiency and efficacy of the police (Proenca and Muniz 2006).

Many respondents, especially those in rural areas, commented on the limited response of both local and district police. Attitudes towards police have become more critical both in respect to controlling crime and helpfulness, with more people stating that police were doing a poor job. Nevertheless, about two-thirds of respondents felt police were helpful and doing a good job in Kampong Cham (compared to $70.5 \%$ in 2001) and over half remained positive to police in Phnom Penh and Kandal (compared to two-thirds in 2001). Despite the significant decline in criminal victimisation, including police corruption and the moderation of the fear of crime, this was not matched by greater public confidence in the police. Other results from the UNICVS support the suggestion that citizens now expect more professional and community oriented policing. Although Cambodians often have a more positive view of their police than many respondents from developed countries, the impact of modernisation also render them less tolerant of crime and more demanding of law enforcement agencies.

\section{Corruption}

The UNICVS also asked respondents about their experience with corruption and their perception of the likelihood of corruption. Most experience with corruption involved elected commune or municipal officials and police, but the pattern varied depending on the location. Significant declines in actual victimisation were observed in Phnom Penh (from $27.8 \%$ in 2000 to $18.2 \%$ in 2005) and also in Kampong Cham (15.6\% in 2000 to $12.9 \%$ in 2006 ) but not in Kandal (18.5\% in 2000 to $18.3 \%$ in 2005). The actual experience of corruption had also decreased with respect to police (except in Kandal). In Phnom Penh, the proportion of victims of police corruption declined from $10.1 \%$ in 2000 to $5.7 \%$ in 2005 
and represented $31.2 \%$ of all victims of corruption compared to $36.5 \%$ in 2000 . In Kampong Cham, the proportion reduced from $4.5 \%$ in 2000 to $2.5 \%$ in 2006 and represented $20.2 \%$ of all victims of corruption compared to $29.1 \%$ in 2000 . In Kandal, however, the experience of corruption by police officers had increased, from $3.5 \%$ in 2000 to $4.4 \%$ in 2005 and represented $24.1 \%$ of all victims of corruption compared to $18.9 \%$ in 2000. In the three provinces, the most frequently cited officials by victims of corruption both in the first and second sweeps were elected commune officials.

The perception that overall corruption by public officials was 'more likely' increased in Kandal and Kampong Cham between 2001 and 2006-2007 (but not in Phnom Penh where it significantly decreased). In the first UNICVS, Cambodians were more likely to consider teachers, doctors and local officials as corrupt than local police; however, in the rural province of Kampong Cham, this sentiment shifted by the second sweep when elected and municipal officials, as well as court officials and police, were perceived as most likely to be corrupt.

Perception of corrupt conduct by police officers had significantly reduced in Phnom Penh, from $28.9 \%$ of respondents who felt police officers were likely to be corrupt in 2001, to $14 \%$ in 2006. However, in Kandal and Kampong Cham, respondents' negative perceptions about the conduct of police officers had increased from $16.7 \%$ in 2001 to $19.8 \%$ in 2006 in Kandal and from $31 \%$ to $60.6 \%$ in Kampong Cham.

\section{Discussion}

The data indicate a substantial decrease in both property and violent crimes. A significant decline in homicide (including extra-judicial homicide) has occurred. Such forms of homicide are indicative of weak formal social control but, with greater regime stability, are far less common in 2006 than in 1998. Given the appalling trauma of the recent past, political conflict, the scale of economic adversity and the rapidity of urbanisation and social changes induced by market development, the current level of homicide is consistent with expectations. More developed neighbours also appear to experience similar levels of homicide but do not share the degree of social desperation or deficits in human assets. Indeed, a rate somewhat lower than would be predicted by an integrated strain and cultural theory of violence may be indicated.

While political stability and disarmament has led to a decrease in group-conflicts and war-legitimated lethal violence (Wille 2006), such events only account for a declining fraction of homicide in Cambodia. The general decline in lethal violence may also reflect the substantial improvements in overall wealth (although the latter is associated with declines in equality per Gini levels, especially in the 1990s) and the steady economic growth that have contributed to a reduction in extreme competition over resources and improvements in some basic services.

Communal traditions, localism and pro-social Buddhist values have prevailed as potent forms of collective protection and could be reinforced by effective governance. The decline in crime shown by the UNICVS also suggests a high degree of social resilience among Khmer, especially in rural areas. These shields may be fragile and are threatened by the tendency of modernity to privilege individuality and materialism. High unemployment among young rural males also appear to be a potential stimulus to crime and disorder and is the focus of concern for many village heads and commune chiefs.

Theoretical implications for crime in a developing economy such as Cambodia are framed by both functionalist and conflict or 'world systems' accounts of crime. Functionalist accounts provide plausible explanations for the decline in violence, but are 
not consistent with the significant reduction in property crime and the apparent convergence between urban and rural areas. The new dynamics of modernisation processes in late twentieth century contexts, including globalisation and international aid mechanisms, may have cancelled or changed the effects of early modernisation phases predicted by orthodox functionalism. This suggests that modernisation theory itself needs to be modernised (or post-modernised) to better fit these new contexts and dynamics, and should give more prominence to the role of cultural influences. Conflict approaches help explain transnational and state crime - notably the entrenched forms of corruption associated with the plunder and rent-seeking of government officials including police, although the experience of street-level corruption in Cambodia has also abated.

This paper provided some assessment of an earlier Australian 'forward' strategy originally justified on humanitarian grounds but now re-designed to prevent, inter alia, a criminal 'safe haven' scenario from arising in Cambodia. As Australia becomes increasingly engaged in overseas police assistance, it is useful to re-assess what may be achieved. The CCJAP example offers such an opportunity, because sufficient time has elapsed to observe meaningful change. The data on crime and victimisation also enables reconsideration of the forms of engagement needed in fragile states (Anderson 2005). These data suggest that assistance via a police reform strategy may provide limited benefits in improved professionalism but that these gains may be compromised by the weakness of the court system and the absence of the political will to address corruption at all levels.

Police reform in fragile states has often failed, and policing institutions have become part of the problem rather than the solution - either because they have been captured by organised crime or have reverted to repressive style regime policing. Although the risks remain significant in the case of Cambodia, the current evidence indicates that policing institutions have continued to struggle against organised crime and sought to legitimise themselves independent of regime politics. In this regard the results seem mixed: while reductions in police violence and actual police corruption are noted, Khmer are less positive and confident in police than in 2000-2001 - when both crime and socio-economic conditions were worse. There are also growing concerns about juvenile crime which, unlike the general trend, appears to be rising. So, possible changes to the fabric of informal social control, induced by modernisation, are underway and create gaps that an under-resourced police force cannot address. Changing attitudes towards crime and higher expectations about what the state should deliver in response to new challenges to social control have also raised the standards expected of police and accordingly public confidence in the police.

\section{Rule of law and the Cambodian state}

The fragmentation of the original civil society by war and genocide has required a conscious effort to re-invent and reproduce the social and moral order of an ideal pre-war Khmer nation. The 1991 Paris Accords reconstituted, under UNTAC supervision, the RGC as a pluralistic state made up of the former SOC, Khmer Rouge and Royalists under the rubric of 'Nation, Religion, King'. The functioning of state institutions and their agents independent of CPP politics remains weak with corruption and cronyism evident. The merging of CPP and the state now seems complete and the 'regime' exercises administration more in terms of traditional patron/client relations than rational allocation of resources.

The transformation of the governance of state security from a military to civil form was a key goal of the first national development plan along with improving food and personal 
security, human rights, health, education and economic development. Under the 1993 UNTAC demobilisation plan, large numbers of former soldiers were placed in policing roles on below subsistence wages. Consequently, the management and discipline of such a large body of armed and ill-trained 'police' has been a major problem and source of impunity. The planned progressive reductions in the number of under-employed untrained police and military personnel required that by 2001 their numbers fall from 137,000 to 67,000. In 2001 this had not occurred; there was doubt about the effectiveness of the demobilisation plan and misuse of funds was identified by donors such as the World Bank (Adams 2001). Reductions in the size of the security forces and weapon availability had been hampered by factional differences in the key Ministries of the Interior (MOI) and Defence until 2003-2004 when CPP domination was completed. Although substantial progress has been made in the reduction of small arms, significant units of the RCAF remain beyond effective civil control or answer only to key officials. This appears to be the case with Brigade 70 and the Prime Minister's powerful bodyguard unit (Global Witness 2007). Thus, the overall civilianising process will continue to be complicated and some units continue to pose formidable risks of violence.

However, while in 1995 the shift required from a military command economy to a market economy was burdened by the $62 \%$ of the RGC revenue absorbed by the security forces (Ministries of Interior and Defence), this has substantially decreased to $18.3 \%$ in 2006 (ADB 2007). In 1998, as little as $10 \%$ of meagre revenues went to education, $6 \%$ to health, and 3\% to agricultural development, but by 2006 budget expenditure on education had increased substantially to reach $19.2 \%$ and health $11.25 \%$ (Konrad Adenauer Foundation cited in Phnom Penh Post 1998, ADB 2003, 2007).

The RGC has operated in the context of a politically divided government of former antagonists - royalists, revolutionaries and socialists. Consequently, state institutions are complex and, until 2004, were open to factional conflicts, and an effective law-making consensual process has not been achieved. Historically, the Kingdom had a weak indigenous bureaucracy based on a French and Vietnamese colonial legacy in which recourse to state and legal institutions was grossly underdeveloped. Traditionally, the Cambodian state was hierarchical, with the revered King, the elite government officials, the villagers and the Buddhist monks all in their place in the complex web of patronage and power. In crucial ways, these traditional, often unmediated, hierarchical relations found their expression in the utopian self-sufficiency programme of the revolutionary (Khmer Rouge) (1975-1979) and continue to shape Cambodian personal and social relationships (Chandler 1992, pp. 53-54). The ceaseless cycles of rice growing that define Khmer village life, impose a natural social order based on communal surveillance, which reduces the need for intervention by the state. Accordingly, the role of police in creating order is limited to the extent that, national uniformity may be required in the context of a devoutly Buddhist society. Pre-existing social identities and relationships account for the form of social order found in rural Cambodia.

The new penal code started in 1994 was not expected to pass the National Assembly until late 2007 and current laws are based on the 1992 UNTAC criminal code. In January 2002 , this was augmented by amendments that strengthened the role of the MOI. The UNTAC code failed to provide a comprehensive ethical system or secure due process consistent with Khmer values, further eroding the legitimacy of law. Court procedural laws were eventually enacted in 2007; however, courts remain a concern and are widely considered unreliable. UN sponsored efforts to rapidly develop a modern court and dispute settlement process included a 'Judicial Mentor Programme' that relied on guidance by overseas judges. This attempt to provide training for court officials (most former SOC 
judges) faltered because the poorly paid judges were prone to corruption or intimidation, and access to courts was prohibitively expensive to all but the elite. A substantial number of offences and disputes are resolved at the commune level without the involvement of provincial or national courts. Therefore, some serious crime and much petty crime and disorder, as everywhere, will be under-reported. The UNICVS data also show that significant levels of crime, although reported, are not recorded.

Supported by international assistance, the RGC has promised to develop a state of rule of law through reforms of the policing institutions, but shortages of human and social capital tend to mobilise under-paid policing institutions according to market forces and not abstract notions of the rule of law. Low salaries, poor training and patron style leadership induce bribery and corruption, and provide the thread of impunity that enables predatory corruption to thrive and challenge or even capture key elements of the state. Widespread concern about elite corruption is not simply a product of lawless behaviour but the absence of effective anti-corruption laws and agencies with the necessary political will to enforce them. The recent discovery of potentially large off-shore reserves of oil and gas (on-stream by 2011) may be the key to the realisation of the worthy goals of poverty reduction and national development, but the large revenues anticipated may also be at risk of misuse by weak institutions dominated by regime elites.

\section{Conclusion}

If the assumption that strong states are more effective at suppressing ordinary crime is valid, then the evidence presented here suggests that the steady assertion of CPP dominance over the security forces has led to a diminution of the more extreme examples of violence. It has reduced competition between faction 'warlords' and ensured greater control over the diverse independent elements that make up the policing apparatus whose loyalty is now associated with a CPP-dominated government. Thus, in seeking legitimacy, the RGC has been able to give priority to security while increasingly diverting resources to other pressing priorities. In this sense, policing in Cambodia may be characterised as regime dependent, and it seems unlikely that the new legislature and King can establish the kind of supra-loyalty amongst these forces that may serve to limit their predatory tendencies and that of the new business elites.

The plural democratic state envisaged by the 1991 Paris Accords, replete with 'checks and balances' and respect for law and human rights, has yet to fully emerge, and elements of the state itself are immune from oversight. In this context, efforts at supporting police professionalism, while pivotal to the rule of law, may be counterproductive given ineffective courts and weak oversight of the executive by the democratically elected legislature.

\section{Notes}

1. For Phase I (1997-2002), AUD12.6 million was allocated, and for Phase II (2002-2007), 18 million.

2. With Kampot, Kampong Spueu, and Kampong Chhnang the total $N$ was 3062.

\section{References}

Adams, B., 2001. Demobilizations' house of mirrors. Phnom Penh Post, 10 (40), 14.

Alvazzi del Frate, A., 1998. Preventing crime: citizens' experience across the world. Issues and reports, 9. Rome: UNICRI. 
Anderson, I., 2005. Fragile states: what is international experience telling us? [online]. Canberra, AusAID. Available from: http://www.AusAID.gov.au/publications/pdf/fragile_states.pdf [Accessed 28 March 2006].

Archer, D. and Gartner, R., 1976. Violent acts and violent times: a comparative approach to post-war homicide rates. American Sociological Review, 41, 937-963.

Arthur, J.A. and Marenin, O., 1995. Explaining crime in developing countries: the need for a case study approach. Crime, Law and Social Change, 23, 191-214.

Asian Development Bank, 2003. Cambodia: country strategy and program update. Manila: Asian Development Bank.

Asian Development Bank, 2007. Asian development outlook [online]. Manila, Asian Development Bank. Available from: http://www.adb.org/Cambodia/default.asp [Accessed 17 May 2007].

AusAID, 2001. Cambodian criminal justice assistance project: feasibility study phase II. Unpublished report. Canberra: AusAID.

AusAID, 2007a. Independent completion report: Cambodia criminal justice assistance Project PCCJAP II (July). Unpublished report. Phnom Penh/Canberra: AusAID.

AusAID, 2007b. Australia's assistance to criminal justice reform in Cambodia: strategic framework document. Unpublished report (May). Phnom Penh/Canberra: AusAID.

Bertrand, R., 2004. Behave like enraged lions: civil militias, the army and the criminalisation of politics in Indonesia. Global Crime, 6 (3/4), 325-344.

Broadhurst, R.G., 2002. Lethal violence and state formation in Cambodia. Australian \& New Zealand Journal of Criminology, 35, 1-26.

Broadhurst, R.G., 2003. Rapporteur's report. In: R.G. Broadhurst, ed. Bridging the GAP: a global alliance perspective on transnational organised crime. Hong Kong: Hong Kong Government Printer/Hong Kong Police, 1-25.

Chandler, D., 1992. A history of Cambodia. Sydney, NSW: Allen and Unwin.

Daly, M. and Wilson, M., 1999. An evolutionary psychology perspective on homicide. In: M.D. Smith and M.A. Zahn, eds. Homicide: a sourcebook of social research. London: Sage, 58-71.

Donias, T., 2005. Back to square one: the politics of police reform in Haiti. Civil Wars, 7 (3), 270-287.

Durkheim, E., 1950. The rules of sociological method. Glencoe, IL: Free Press.

Elias, N., 1994. The civilizing process. Oxford: Blackwell.

Evans, P.B., Rueschemeyer, D., and Skocpol, T., eds, 1985. Bringing the state back. New York: Cambridge University Press.

Ghai, Y., 2007. Implementation of General Assembly resolution 60/251 of 15 March 2006 entitled 'Human rights council'. Report of the Special Representative of the Secretary General for Human Rights in Cambodia, A/HRCl, 4/36.

Global Witness, 2007. Cambodia's family trees: illegal logging and the stripping of public assets by Cambodia's elite. Washington DC: Global Witness.

Hughes, C., 2006. Violence and voting in post-1993 Cambodia. In: A. Croissant, B. Martin, and S. Kneip, eds. The politics of death: political violence in Southeast Asia. Muenster \& Hamburg: Lit Verlag, 319-342.

Johnson, E.A. and Monkkonen, E.H., eds, 1996. The civilization of crime: violence in town and country since the Middle Ages. Chicago: University of Illinois Press.

LaFree, G.A., 1999. Summary and review of cross-national comparative studies of homicide. In: M.D. Smith and M.A. Zahn, eds. Homicide: a sourcebook of social research. London: Sage, 125145.

Men, B., et al., 2005. Key issues relating to decentralization at the provincial level of health management in Cambodia. International Journal of Health and Management, 20 (1), 3-19.

Murshid, K.A.S., 1998. Food security in an Asian transitional economy - the Cambodian experience. Working Paper, VI. Phnom Penh: Cambodian Development Resource Centre.

Neopolitan, J.L., 1997. Homicides in developing nations: results of research using a large and representative sample. International Journal of Offender Therapy and Comparative Criminology, 41, 358-374.

Newman, G., 1999. Global report on crime and justice. New York: UN Office of Drug Control \& Crime.

Peou, S., 2000. Change and regime change in Cambodia: toward democracy? London: St. Martin's Press. 
Peou, S., 2006. Consolidation or crisis of democracy? Cambodia's parliamentary election in 2003 and beyond. In: A. Croissant, B. Martin, and S. Kneip, eds. Between consolidation and crisis. Hamburg: Lit Verlag, 41-84.

Phnom Penh Post, 1998-2006. Police blotter. Phnom Penh Post, Vol 7-16 (Weekly).

Proenca, D. Jr. and Muniz, J., 2006. Stop or I will call the police: the idea of police, or the effects of police encounters over time. British Journal of Criminology, 46, 234-257.

Skogan, W., 2007. Survey assessments of police performance. In: M. Hough and M. Maxfield, eds. Surveying crime in the 21st century. Cullompton: Willan, 165-182.

Wille, C., 2006. Finding the evidence: the links between weapon collection programmes, gun use and homicide. African Security News, 15 (2), 59-70. 